Received 00th January 20xx Accepted 00th January 20xx

\section{Synthesis and properties of a novel narrow band gap oligomeric diketopyrrolopyrrole-based organic semiconductor}

\author{
Mylène Le Borgne ${ }^{a, b}$, Jesse Quinn ${ }^{b}$, Jaime Perez ${ }^{c}$, Natalie Stingelin ${ }^{c}$, Guillaume Wantz ${ }^{a}$ and \\ Yuning $\mathrm{Li}^{\mathrm{b} *}$
}

An oligomeric semiconductor containing three bisthiophenediketopyrrolopyrole units (Tri-BTDPP) was synthesized and characterized. Tri-BTDPP has a HOMO level of $-5.34 \mathrm{eV}$, a broad absorption close to the near infrared region and a low band gap of $1.33 \mathrm{eV}$. Additionally, a promising hole mobility of $1 \times 10^{-3} \mathrm{~cm}^{2} \mathrm{~V}^{-1} \mathrm{~s}^{-1}$ was achieved after thermal annealing at $150{ }^{\circ} \mathrm{C}$ in organic field effect transistors (OFET). Organic photovoltaic (OPV) cells containing Tri-BTDPP and $P C_{71} B M$ as the donor/acceptor couple exhibited a power conversion efficiency (PCE) of $0.72 \%$. Through an intensive study of the active layer using AFM, XRD, and DSC, it was found that Tri-BTDPP and PC $_{71} B M$ were unable to intermix effectively, resulting in oversized Tri-BTDPP crystalline phases and thus poor charge separation. Strategies to improve the OPV performance were thus proposed.

\footnotetext{
a. Univ. Bordeaux, IMS, UMR 5218, F-33400, Talence, France : CNRS, IMS, UMR 5218, F-33400, Talence, France

Bordeaux INP, IMS, UMR 5218, F-33400, Talence, France

Dept of Chemical Engineering, University of Waterloo, 200 University Ave West,

Waterloo, ON N2L 3G1, Canada

Dept of Materials and Centre for Plastic Electronics, Imperial College London, London, UK

t Footnotes relating to the title and/or authors should appear here. Electronic Supplementary Information (ESI) available: [details of any supplementary information available should be included here]. See DOI: $10.1039 / x 0 x x 00000 x$
} 


\section{Introduction}

Organic photovoltaic (OPV) solar cells represent a promising technology to provide sustainable and cost-effective energy, which can be produced using printing technologies. They have attracted enormous attention from the scientific community and industry for the last 20 years. Semiconducting polymers were the first promising materials to be introduced in OPV devices. Recently, however solution-processed small molecules ${ }^{1-4}$ have demonstrated very promising performance and are currently receiving increasing attention. Small molecule organic semiconductors have well-defined structures and much higher purity than their polymer counterparts. Their syntheses do not suffer from large batch-to-batch variation as those of polymers, although small molecules present poor film formation capability by solution processing compared with polymers. Consequently, OPVs based on solution-processed small molecules often suffer from low fill factors (FF). To improve the solution processability while maintaining other merits of small molecules, oligomeric organic semiconductors with molecular weights between those of polymers and small molecules are being studied extensively. The best power conversion efficiencies (PCE) to date are in the range of $6-9 \%,{ }^{5-7}$ values comparable to those of polymer solar cells. $^{8-10}$

Diketopyrrolopyrrole (DPP) is currently the most widely studied electron-accepting building block for constructing low band gap semiconductors including small molecules, oligomers, and polymers for OPVs. DPP-based solution-processed small molecules were first introduced by Nguyen and co-workers in 2008 as donors in OPVs. ${ }^{11}$ Since then, various solution processed small molecules/oligomers based on DPP have been reported with PCEs as high as $5 \% .{ }^{12-15}$ A series of oligomers consisting of two DPP terminal units and different cores such as naphtodithiophene and benzodithiophene (DPP-Core-DPP) were reported to achieve a PCE of 4-5\%. ${ }^{15,16}$ In 2013, Nguyen's group reported two tri-DPP (DPP trimers) made of one bisphenyl-DPP and two bisthiophene DPP. ${ }^{12,17}$ The use of triDPP improved the charge transport, the quality of the film and the fill factor of the device. These improvements resulted in a PCE of 5.5\%. Here, we report a Tri-DPP oligomer consisting of three bisthiophene DPP units in order to achieve a coplanar structure. A coplanar molecular geometry is expected to contribute to greater crystallinity, improved charge transport, and a lower band gap of the semiconductor. We used this new DPP compound as an electron donor (combined with $\mathrm{PC}_{71} \mathrm{BM}$ ) in OPV devices.

\section{Experimental section}

\subsection{Materials and measurements}

All reagents and chemicals were purchased from commercial sources (Sigma Aldrich, Alpha Aesar) and used without further purification. 3-(5-Bromothiophen-2-yl)-2,5-bis(2-ethylhexyl)-6(thiophen-2-yl)-2,5-dihydropyrrolo[3,4-c]pyrrole-1,4-dione (1) and

2,5-bis(2-octyldodecyl)-3,6-bis(5-

(trimethylstannyl)thiophen-2-yl)-2,5-dihydropyrrolo[3,4-

c]pyrrole-1,4-dione (2) were prepared as described in the literature. ${ }^{18,19}$

All ${ }^{1} \mathrm{H}$ NMR and ${ }^{13} \mathrm{C}$ NMR spectra were recorded on a 400 $\mathrm{MHz}$ and $300 \mathrm{MHz}$ Bruker NMR using $\mathrm{CDCl}_{3}$ as solvent and tetramethylsilane (TMS, $0 \mathrm{ppm}$ ) as a reference. High resolution electrospray technique mass spectrometry was used for TriBTDPP and MALDI-TOF for by-product. Cyclic voltammetry (CV) measurements were conducted using a DY2000EN electrochemical workstation in a $0.1 \mathrm{M}$ tetrabutylammonium hexafluorophosphate acetonitrile electrolyte at room temperature at a scan rate of $50 \mathrm{mV} \mathrm{s}^{-1}$. The working electrode and counter electrode were platinum electrodes and the reference electrode was $\mathrm{Ag} / \mathrm{AgCl}(0.1 \mathrm{M})$ electrode. The reference electrode was calibrated against the redox potential of ferrocene/ferrocenium $\left(\mathrm{Fc} / \mathrm{Fc}^{+}\right)$. The thin film on the Pt disk, formed by drop-casting a chloroform solution was used as the working electrode. AFM imaging was carried out at room temperature using an AFM Nanoman from Bruker Instrument with Nanoscope 5 controller. Images were obtained in tapping mode using silicon tips (PointProbe ${ }^{\circledR}$ Plus AFM-probe, Nanosensors, Switzerland). ,DSC, XRD.

\subsection{Device and characterization}

The photovoltaic properties were tested in conventional solar cells and inverted solar cells following respectively those structures: ITO/PEDOT:PSS/Tri:BTDPP:PC ${ }_{71} \mathrm{BM} /(\mathrm{Ca}) / \mathrm{Al}$ and

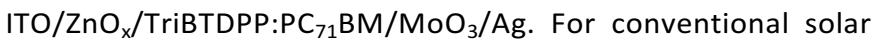
cells fabrication, ITO-coated glass substrates were successively cleaned in ultrasonic baths of acetone/ethanol/isopropanol for $10 \mathrm{~min}$, followed by oxygen plasma treatment for $15 \mathrm{~min}$. A water solution of PEDOT:PSS, previously filtrated on $0.2 \mu \mathrm{m}$, was deposited by spin-coating at $4000 \mathrm{rpm}$ for $60 \mathrm{sec}$. The layer was dried in the oven at $100^{\circ} \mathrm{C}$ under vacuum for $30 \mathrm{~min}$. Then, a solution of Tri-BTDPP:PC ${ }_{71} \mathrm{BM}\left(1: 1,15 \mathrm{mg} \mathrm{ml}^{-1}\right)$ in chloroform and 1 vol\% DIO were spin-coated on top of PEDOT:PSS under nitrogen atmosphere. The thickness of the active layer was 90 $\mathrm{nm}$. The solvent were removed by annealing the active layer at $80{ }^{\circ} \mathrm{C}$ for 10 minutes. Calcium $(10 \mathrm{~nm})$ and then aluminum (80 $\mathrm{nm}$ ) were thermally evaporated onto the active layer through shadow masks under $2-4 \times 10^{-6} \mathrm{mbar}$. The effective area was 10 $\mathrm{mm}^{2}$.

For inverted solar cell, after similarly pre-cleaned the ITOcoated substrates, a solution of $\mathrm{ZnO}_{\mathrm{x}}$ prepared with $0.15 \mathrm{M}$ of zinc acetate and $0.15 \mathrm{M}$ of ethanol amine in ethanol was spincoated at $2000 \mathrm{rpm}$ for $60 \mathrm{sec}$. The layer was annealed at 180 ${ }^{\circ} \mathrm{C}$ for $1 \mathrm{~h}$. The active layer was prepared and deposited as for conventional solar cell. To complete the device, molybdenum (IV) oxide $(10 \mathrm{~nm})$ and silver $(80 \mathrm{~nm})$ were thermally evaporated onto the active layer through shadow masks under $2-4 \times 10^{-6}$ mbar. The effective area was $10 \mathrm{~mm}^{2}$.

The devices were characterized using a K.H.S SolarCelltest575 solar simulator with AM $1.5 \mathrm{G}$ filters set at $100 \mathrm{~mW} \mathrm{~cm}^{-2}$ with a calibrated radiometer (IL 1400BL). The current density- 
voltage (J-V) curves measurements were processed with Labview controlled Keithley 2400 SMU. Devices were characterized under nitrogen in a set of glove boxes $\left(\mathrm{O}_{2}\right.$ and $\mathrm{H}_{2} \mathrm{O}$ $<0.1 \mathrm{ppm}$ ).

Bottom gate - bottom contacts field effect transistors were fabricated (OFETs) using Fraunhofer IPMS templates of doped Si with $200 \mathrm{~nm}$-thick silicon oxide and gold electrodes. Substrates were cleaned with successive acetone and IPA baths followed by $15 \mathrm{~min}$ of UV-ozone treatment. A solution of $5 \mathrm{mg} \mathrm{ml}^{-1}$ of TriBTDPP in chloroform was spin-coated at $2500 \mathrm{rpm}$ for $40 \mathrm{sec}$ on top of transistor substrates in the nitrogen-filled glovebox to form a $40 \mathrm{~nm}$-thick layer. The dimensions of the channel were $\mathrm{L}=5 \mu \mathrm{m}$ and $\mathrm{W}=1 \mathrm{~cm}$. Transistors were measured using an analyzer for semiconductor (Keithley 4200) coupled with a three tip station.

\subsection{Synthesis}

6,6'-((2,5-bis(2-octyldodecyl)-3,6-dioxo-2,3,5,6tetrahydropyrrolo[3,4-c]pyrrole-1,4-diyl)bis([2,2'bisthiophenel-5',5-diyl))bis(2,5-bis(2-ethylhexyl)-3(thiophen-2-yl)-2,5-dihydropyrrolo[3,4-c]pyrrole-1,4-dione) (Tri-BTDPP). A $100 \mathrm{ml}$ dry three-necked round bottom flask was charged with compound 1 (1.5 g, $0.0025 \mathrm{~mol}, 2.1 \mathrm{eq})$, compound 2 ( $1.40 \mathrm{~g}, 0.0012 \mathrm{~mol}, 1 \mathrm{eq}), \mathrm{P}(\mathrm{o}-\mathrm{tolyl})_{3}(28.7 \mathrm{mg}, 0.09$ $\mathrm{mmol}, 0.08 \mathrm{eq})$ and anhydrous toluene $(49 \mathrm{~mL})$ under argon. Then, $\mathrm{Pd}_{2}(\mathrm{dba})_{3}(21.9 \mathrm{mg}, 0.024 \mathrm{mmol}, 0.02 \mathrm{eq})$ dissolved in anhydrous toluene $(1 \mathrm{~mL})$ was added into the flask through a syringe. The mixture was heated at $120^{\circ} \mathrm{C}$ for $60 \mathrm{~h}$ during which the color of the solution turned from purple to blue. After cooling down to room temperature, the solution was poured into methanol $(600 \mathrm{~mL})$ and stirred for $30 \mathrm{~min}$. The resulting precipitate was filtered and purified using column chromatography on silica gel with a mixture of dichloromethane (DCM) and hexane (with a volume ratio of 6:4) and then pure chloroform as eluent to afford $1.65 \mathrm{~g}(72 \%)$ of the crude product and $0.60 \mathrm{~g}(26 \%)$ of $6,6^{\prime}-\left(\left[2,2^{\prime}-\right.\right.$ bithiophene $]-5,5^{\prime}$-diyl)bis(2,5bis(2-ethylhexyl)-3-(thiophen-2-yl)-2,5-dihydropyrrolo[3,4-

c]pyrrole-1,4-dione) (3), a by-product formed by the monocoupling of compound 1 and 2 . The crude product obtained by the first column separation contains the target Tri-BTDPP and the by-product 3-(5'-(2,5-bis(2-ethylhexyl)-3,6-dioxo-4(thiophen-2-yl)-2,3,5,6-tetrahydropyrrolo[3,4-c]pyrrol-1-yl)[2,2'-bithiophen]-5-yl)-2,5-bis(2-octyldodecyl)-6-(thiophen-2yl)-2,5-dihydropyrrolo[3,4-c]pyrrole-1,4-dione (4), formed by the homo-coupling of $1.0 .50 \mathrm{~g}$ of this crude product was further purified on silica gel column chromatography at $50{ }^{\circ} \mathrm{C}$ using a mixture of chloroform/toluene (volume ratio: $1 / 1$ ) as eluent to afford $0.39 \mathrm{~g}$ pure Tri-BTDPP as a dark blue solid and $0.11 \mathrm{~g}$ of the by-product 4 . The total amounts of Tri-BTDPP and 4 in 1.65 $\mathrm{g}$ of the crude product are estimated to be $1.29 \mathrm{~g} \mathrm{(56 \% )}$ and 0.36 g (16\%), respectively. Data for Tri-BTDPP: ${ }^{1} \mathrm{H}$ NMR $(400 \mathrm{MHz}$; $\left.\mathrm{CDCl}_{3}\right) \delta 8.93(2 \mathrm{H}, \mathrm{d}, \mathrm{J}=4.2 \mathrm{~Hz}), 8.91(2 \mathrm{H}, \mathrm{d}, \mathrm{J}=4.2 \mathrm{~Hz}), 8.85(2 \mathrm{H}$, $\mathrm{dd}, \mathrm{J}=3.9,1.1 \mathrm{~Hz}), 7.49(2 \mathrm{H}, \mathrm{dd}, \mathrm{J}=5.0,1.0 \mathrm{~Hz}), 7.25(4 \mathrm{H}, \mathrm{dd}, \mathrm{J}$ $=3.9,3.5 \mathrm{~Hz}), 7.14(2 \mathrm{H}, \mathrm{dd}, \mathrm{J}=4.9,4.0 \mathrm{~Hz}), 3.96(12 \mathrm{H}, \mathrm{d}, \mathrm{J}=5.2$ $\mathrm{Hz}), 2.00-1.71(6 \mathrm{H}, \mathrm{m}), 1.39-1.23(35 \mathrm{H}, \mathrm{m}), 1.22-1.05(70 \mathrm{H}$, $\mathrm{m}), 0.92-0.72(41 \mathrm{H}, \mathrm{m}) .{ }^{13} \mathrm{C} \mathrm{NMR}\left(400 \mathrm{MHz}, \mathrm{CDCl}_{3}\right) \delta 161.81$, $161.69,141.49,141.19,140.67,139.33,139.28,137.43,137.15$, $135.95,131.03,130.14,130.02,129.95,128.77,126.12,109.37$, $109.08,108.44,77.56,46.76,46.30,39.73,39.46,38.41,32.26$,
$32.24,31.60,30.68,30.56,30.51,30.45,30.05,29.99,29.97$, 29.92, 29.72, 29.70, 28.84, 28.69, 26.65, 24.02, 23.87, 23.47, $23.44,23.03,14.45,14.38,10.91,10.83$. HR-MS: $\mathrm{m} / \mathrm{z}$ 1906.11094 $\left(\mathrm{M}^{+}, 90 \%\right)$

Data for 3: NMR $\left(300 \mathrm{MHz} ; \mathrm{CDCl}_{3}\right) \delta 9.05-8.84(4 \mathrm{H}, \mathrm{m}), 7.65(2 \mathrm{H}$, $\mathrm{d}, \mathrm{J}=4.9 \mathrm{~Hz}), 7.43(2 \mathrm{H}, \mathrm{d}, \mathrm{J}=4.2 \mathrm{~Hz}), 7.33-7.28(1 \mathrm{H}, \mathrm{m}), 7.23-$ $7.18(1 \mathrm{H}, \mathrm{m}), 4.04(8 \mathrm{H}, \mathrm{d}, \mathrm{J}=7.1 \mathrm{~Hz}), 1.92(4 \mathrm{H}, \mathrm{s}), 1.44-1.07(8 \mathrm{H}$, $\mathrm{m}), 1.04-0.67(26 \mathrm{H}, \mathrm{m})$.

Data for 4: MALDI-TOF: m/z $1046.4\left(\mathrm{M}^{+}, 100 \%\right)$

\section{Results and discussion}

\subsection{Synthesis and characterization}
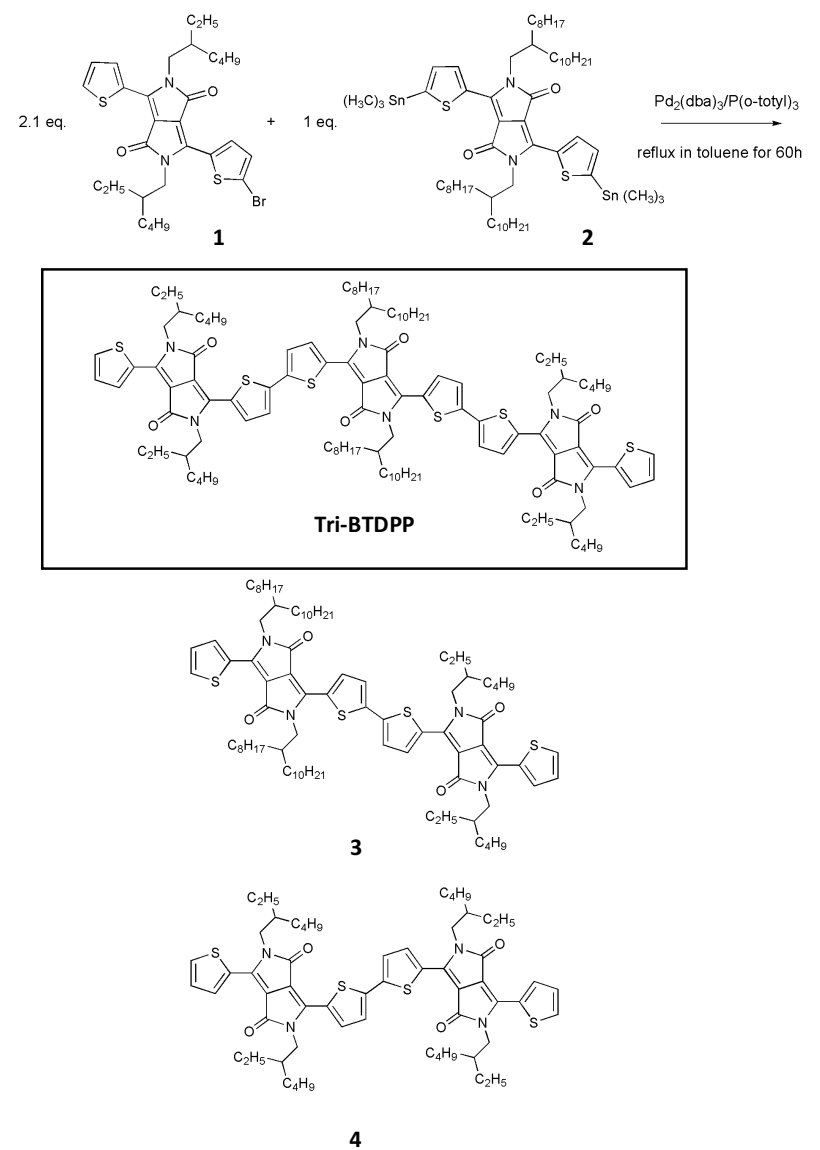

Scheme 1 Synthetic route to Tri-BTDPP via Stille coupling reaction of 1 and 2

The synthesis route to $6,6^{\prime}$-((2,5-octyldodecyl)-3,6-dioxo2,3,5,6-tetrahedropyrrolo[3,4-c]pyrrole-1,4-diyl) bis([2,2' bisthiophene]-5',5-diyl))bis(2,5-bis(2-ethylhexyl)-3-(thiophen2-yl)-2,5-dihydropyrrolo[3,4-c]pyrrole-1,4-dione) (Tri-BTDPP) is shown in Scheme 1 . The mono-brominated DPP compound 1 and the bis(trimethylstannyl) DPP compound $\mathbf{2}$ were synthesized according to the methods reported in the literature ${ }^{18,19}$. The introduction of the long 2-octyldodecyl side chain on 2 was intended to render the final compound TriBTDPP solution-processable. The synthesis of Tri-BTDPP was conducted via Stille cross coupling reaction between $\mathbf{1}$ and $\mathbf{2}$ in 
a 2.1:1 molar ratio in toluene under reflux for $60 \mathrm{~h}$ in the presence of $\mathrm{Pd}_{2}(\mathrm{dba})_{3} / \mathrm{P}(\mathrm{o} \text {-tolyl })_{3}$ as a catalyst. Separation of the target product Tri-BTDPP was accomplished by column chromatography, which was not straightforward due to the close polarity of the Tri-BTDPP and a by-product 4 , which was formed by the homo-coupling of compound 1 . First, column chromatography on silica gel using DCM:hexane and then chloroform was conducted to remove compound 3 (26\%) and other impurities to yield a crude product $(72 \%)$, which still contained compound 4. Further purification was conducted by using a heated $\left(50^{\circ} \mathrm{C}\right)$ silica gel column using a mixture of chloroform and toluene (with a volume ratio of 1:1) as eluent, which enabled separation of Tri-BTDPP and 4. Pure Tri-BTDPP was obtained in $56 \%$ yield, with the molecular structure confirmed by NMR and ESI mass spectrometry. The yield of homo-coupling dimer by-product 4 yield was 16\%. Compound 4 was characterized by MALDI-TOF mass spectrometry. NMR spectra could not be obtained for $\mathbf{4}$ due to the strong aggregation tendency of this compound. Formation of a notable quantity $(\sim 16 \%)$ of homo-coupling by- product in a Stille coupling of a similar brominated DPP compound under similar conditions was recently reported. ${ }^{20}$ Other types of catalysts such as $\mathrm{Pd}\left(\mathrm{PPh}_{3}\right)_{4}$ may be used to improve the yields of the target Tri-BTDPP.

Among the solvents tested (hexane, chloroform, toluene, chlorobenzene and $o$-dichlorobenzene), only chloroform provides a solubility above $10 \mathrm{mg} \mathrm{mL}^{-1}$ for Tri-BTDPP, which confirms the need of long alkyl chains on the central DPP unit. The thermal properties of Tri-BTDPP were studied by differential scanning calorimetry (DSC). Tri-BTDPP presents an exothermic peak corresponding to its melting point at $253^{\circ} \mathrm{C}$ in the heating scan and an endothermic peak at $232{ }^{\circ} \mathrm{C}$ corresponding to its crystallization temperature in the cooling scan. Tri-BTDPP has a strong tendency to crystallize as its crystallization enthalpy is equal to $87 \%$ of its melting enthalpy.

\subsection{Optical properties}

The UV-Vis absorption spectra of Tri-BTDPP in chloroform solution and neat film are shown in Fig. 1. Tri-BTDPP absorbs in the range of 600 to $850 \mathrm{~nm}$ in solution with the maximum absorption peak $\left(\lambda_{\max }\right)$ at $707 \mathrm{~nm}\left(\lambda_{\max }\right)$. Compared with the TriDPP containing a central bisphenyl DPP unit, which shows absorption onsets at $\sim 670 \mathrm{~nm},{ }^{12,17}$ Tri-BTDPP presents a much longer absorption onset at $\sim 810 \mathrm{~nm}$, owing to the increased conjugation length as a result of higher coplanarity and a more efficient intramolecular charge transfer from the electrondonating thiophene units to the central electron-accepting DPP unit. In film, the $\lambda_{\max }$ red-shifts to $725 \mathrm{~nm}$ and an additional shoulder at $\sim 830 \mathrm{~nm}$ appears. The spectrum extends up to 1000 $\mathrm{nm}$. The red-shift of the absorption spectrum from solution to film originates from the planarization of the molecule and the strong intermolecular interactions in the solid state. The optical band gap $\left(E_{g}\right)$ was calculated from the onset absorption wavelength to be $1.33 \mathrm{eV}$, which fell in the range of $1.2 \mathrm{eV}$ to
$1.7 \mathrm{eV}$ needed for optimal harvesting of sunlight to achieve a high PCE. ${ }^{22}$

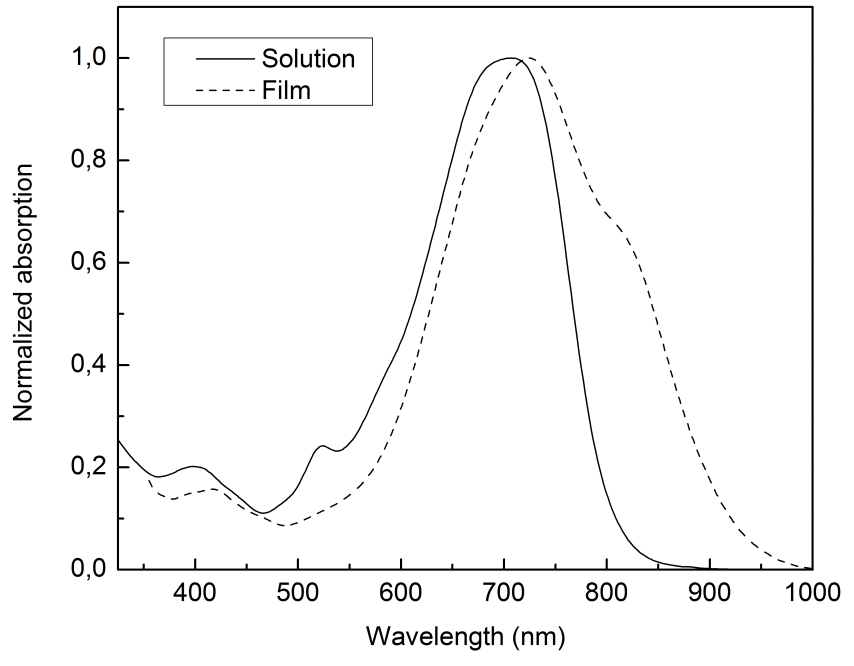

Fig. 1 UV-Visible spectra of tri-BTDPP in solution and in film.

\subsection{Electrochemical properties and theoretical calculations}

Density functional theory (DFT) calculations were carried out on Tri-BTDPP to study its optimizedmolecular geometry and energy levels. The Beckès three parameter exchange functional and LYP correlation functional (B3LYP) were employed on the standard 6-31G basis set to define the lowest energy conformation. In addition, methyl side chains were chosen to speed up the calculation. As shown in Fig. 2, Tri-BTDPP assumes a coplanar structure as the lowest energy conformation, which would be beneficial for intermolecular interactions and close $\pi-\pi$ stacking. It can also be seen that the highest occupied molecular orbital (HOMO) and the lowest unoccupied molecular orbital (LUMO) extend over the entire molecule, revealing an efficient conjugation and intramolecular charge transfer (ICT) between thiophene and DPP moieties. The theoretical values of the HOMO and LUMO levels were evaluated to be $-4.76 \mathrm{eV}$ and $3.15 \mathrm{eV}$, respectively.

The electrochemical properties of Tri-BTDPP were investigated by cyclic voltammetry (CV). The data are summarized in Table 1. The HOMO level was calculated from the onset of the first oxidation peak using the equation: $\mathrm{E}_{\mathrm{HOMO}}=$ - $\left(\mathrm{E}_{\mathrm{ox}}{ }^{\text {onset }}-\left(\mathrm{E}^{\mathrm{Fc}}-4.8\right)\right) \mathrm{eV}$, where $-4.8 \mathrm{eV}$ is the HOMO energy level of ferrocene $(\mathrm{Fc}) .^{21}$ Since no reduction peak was observed, the LUMO was estimated by adding the optical band gap to the HOMO. The HOMO and the LUMO of Tri-BTDPP were respectively evaluated to be $-5.34 \mathrm{eV}$ and $-3.99 \mathrm{eV}$. For a given acceptor, the HOMO level of a donor dictates the open circuit voltage $\left(\mathrm{V}_{\mathrm{oc}}\right)$ of the resulting OPV devices. Based on Scharber's methods, ${ }^{22}$ a theoretical $V_{\text {oc }}$ value of $0.74 \mathrm{eV}$ can be attributed for a blend of Tri-BTDPP and PCBM. Additionally, they reword a diagram predicting the best PCE that can be achieved by a specific donor/PCBM system according to the energy levels. Using Tri-BTDPP as donor material, a PCE of $10 \%$ can be predicted. Although achieving such a PCE requires an ideal morphology and efficient and balanced charge transport, this 
analysis confirmed that Tri-BTDPP is a promising donor for organic solar cells.

a)

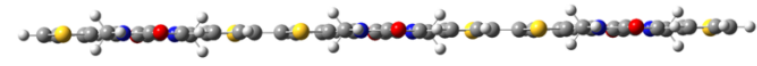

b)

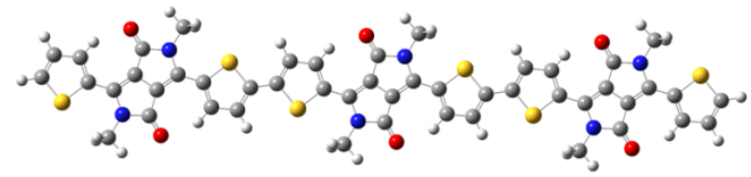

c

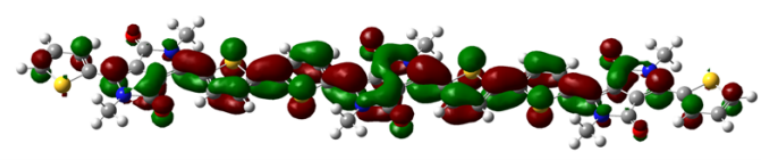

LUMO

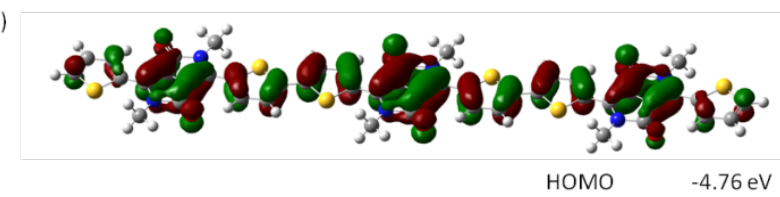

Fig. 2 DFT calculations of Tri-BTDPP. a-b) Lowest energy conformation; c-d) Frontier orbitals.

Table 1 Theoretical and experimental energy levels.

\begin{tabular}{lccc}
\hline & $\begin{array}{c}\text { HOMO } \\
(\mathrm{eV})\end{array}$ & $\begin{array}{c}\text { LUMO } \\
(\mathrm{eV})\end{array}$ & $\begin{array}{c}\mathrm{E}_{\mathrm{g}} \\
(\mathrm{eV})\end{array}$ \\
\hline DFT & -4.76 & -3.15 & 1.61 \\
$\mathrm{CV}$ & -5.34 & -3.99 & 1.33 \\
\hline
\end{tabular}

\subsection{Charge transport and photovoltaic properties}

The charge transport property of Tri-BTDPP was studied using bottom-gate bottom-contact field effect transistors (OFETs) using $\mathrm{n}$-doped $\mathrm{Si} / \mathrm{SiO}_{2}$ wafer substrates. The devices showed p-type hole transport performance. The average saturation hole mobility of the as-cast thin films was evaluated to be $1.21 \times 10^{-4} \mathrm{~cm}^{2} \mathrm{~V}^{-1} \mathrm{~s}^{-1}$. The devices with Tri-BTDPP films annealed at $100{ }^{\circ} \mathrm{C}$ and $150^{\circ} \mathrm{C}$ for $10 \mathrm{~min}$ exhibited higher hole mobilities with an average value of $7.44 \times 10^{-4} \mathrm{~cm}^{2} \mathrm{~V}^{-1} \mathrm{~s}^{-1}$ and $9.41 \times 10^{-4} \mathrm{~cm}^{2} \mathrm{~V}^{-1} \mathrm{~s}^{-1}$ respectively, indicating improved molecular ordering in the films upon annealing. Fig. 3 shows the transfer and output curves of the best device, annealed at 150 ${ }^{\circ} \mathrm{C}$, which shows the highest mobility of $1.22 \times 10^{-3} \mathrm{~cm}^{2} \mathrm{~V}^{-1} \mathrm{~s}^{-1}$.

The photovoltaic properties of a blend of Tri-BTDPP as a donor and $[6,6]$-phenyl- $\mathrm{C}_{71}$ - butyric acid methyl ester ( $\left.P C_{71} \mathrm{BM}\right)$ as an acceptor were investigated in bulk heterojunction ( $\mathrm{BHJ}$ ) solar cells. Here, we detail several optimizations made of the device architectures and the ink formulation. First, a conventional architecture, ITO/PEDOT:PSS/Tri-BTDPP:PC ${ }_{71} B M$ /AI, was used. The active layer was deposited by spin-coating a solution of Tri-BTDPP:PC ${ }_{71} \mathrm{BM}$ in chloroform. After optimizing the thickness of the active layer and the Tri-BtDPP:PC ${ }_{71} B M$ ratio, the PCE was $<0.1 \%\left(\mathrm{~V}_{\text {oc }}=0.36 \mathrm{~V} ;(\mathrm{FF})=0.28\right.$; short circuit current density $\left.\left(\mathrm{J}_{\mathrm{sc}}\right)=0.56 \mathrm{~mA} \mathrm{~cm}^{-2}\right)$. The poor performance was most likely due to a poor morphology, specifically, a poor nanophase separation of the donor and acceptor in the films (see discussion below). Using solvent additives is an efficient way to tailor the morphology and to improve the solar cell performances. ${ }^{23,24}$ We used 1,8-diiodooctane (DIO), which is one of the most commonly used additives, to improve the film morphology of the Tri-BTDPP:PC ${ }_{71} \mathrm{BM}$ blend. Different concentrations (vol\% relative to the solvent) of DIO $(0.25 \%$, $0.5 \%, 1 \%, 2 \%, 3 \%, 4 \%$ and $5 \%$ ) were added in the blends. With $1 \%$ DIO, a PCE of $0.27 \%$ was obtained. Further increase in DIO concentration did not result in further improvement in the cell performance.

In order to improve the charge collection, a thin layer ( 10 $\mathrm{nm}$ ) of calcium ( $\mathrm{Ca}$ ) was introduced between the active layer and the aluminum electrode. The PCE increased to $0.43 \%$. Next, an inverted solar cell structure, ITO/ZnO $/$ Tri-BTDPP:PC ${ }_{71} \mathrm{BM}$ $/ \mathrm{MoO}_{3} / \mathrm{Ag}$, was adopted to further improve the charge collection. Higher $\mathrm{J}_{\mathrm{sc}}$ of $2.15 \mathrm{~mA} \mathrm{~cm}^{-2}$ and $\mathrm{V}_{\mathrm{oc}}$ of $0.67 \mathrm{~V}$ were

achieved, which led to an increased PCE up to $0.72 \%$. However, the cell performance is still very low compared to other small molecules reported in the literature, mainly due to the low $\mathrm{J}_{\mathrm{sc}}{ }^{25}$

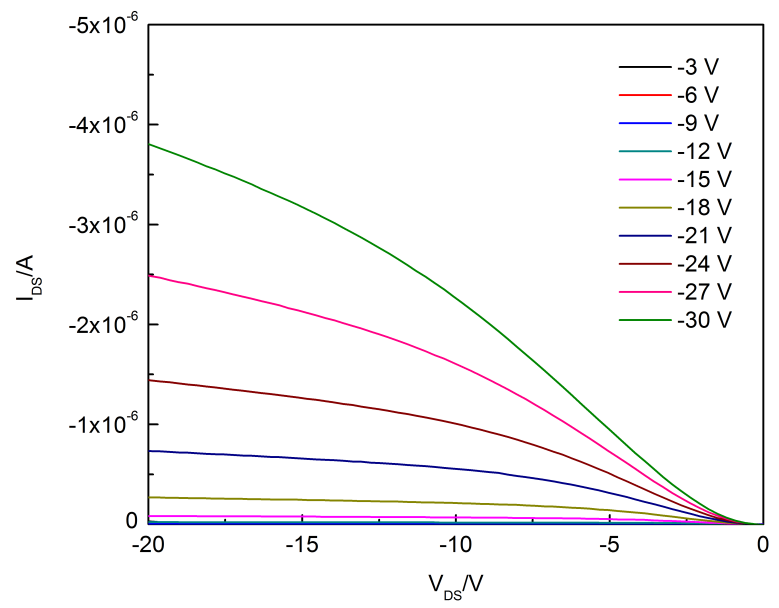




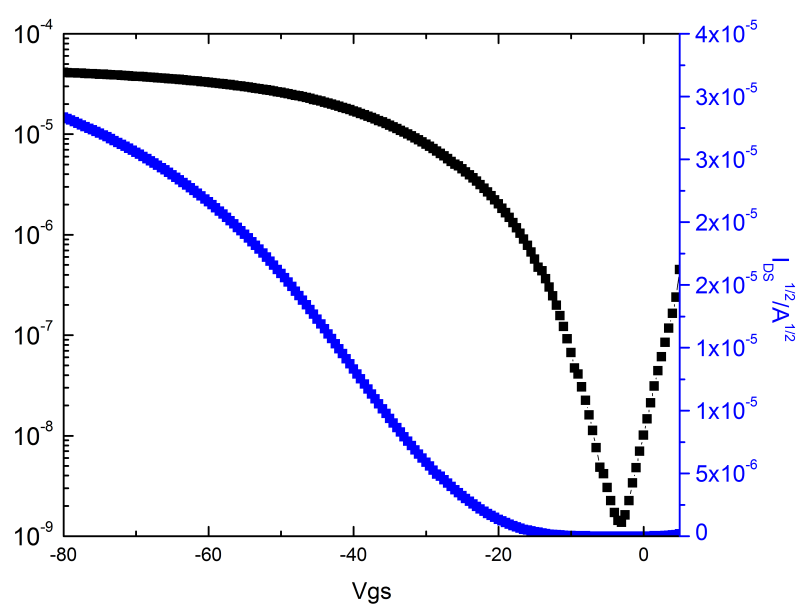

Table 2

Photovoltaic

performances in $\mathrm{BHJ}$ solar cells with different architectures
3 Field effect transistors characterizations after $150^{\circ} \mathrm{C}$ annealing: a) sfer curve at $\mathrm{V}_{G S}=30 \mathrm{~V}$ and $\mathrm{b}$ ) output curves.
For these reasons, the size of the domains should be reduced to improve the charge separation.

Fig. 4 AFM heigh (a) and phase (b) images $0.5 \mu \mathrm{m} \times 0.5 \mu \mathrm{m}$ of Tri-BTDPP: PC ${ }_{71}$ BM (1:1) film from chloroform and $1 \%$ vol DIO solution

To further understand the composition and the origin of the morphology, the interaction of Tri-BTDPP and $\mathrm{PC}_{71} \mathrm{BM}$ was investigated using differential scanning calorimetry (DSC). The measurements were completed on films prepared by dropcasting solutions of Tri-BTDPP and PC $_{71} \mathrm{BM}$ with different ratios in chloroform. The DSC trace of the first heating scan of each sample is shown in Fig. 6 . The melting points of both Tri-BTDPP and $P C_{71} B M$ appear independent of the blend ratio, revealing their immiscibility. This indicates that Tri-BTDPP and $\mathrm{PC}_{71} \mathrm{BM}$ do not

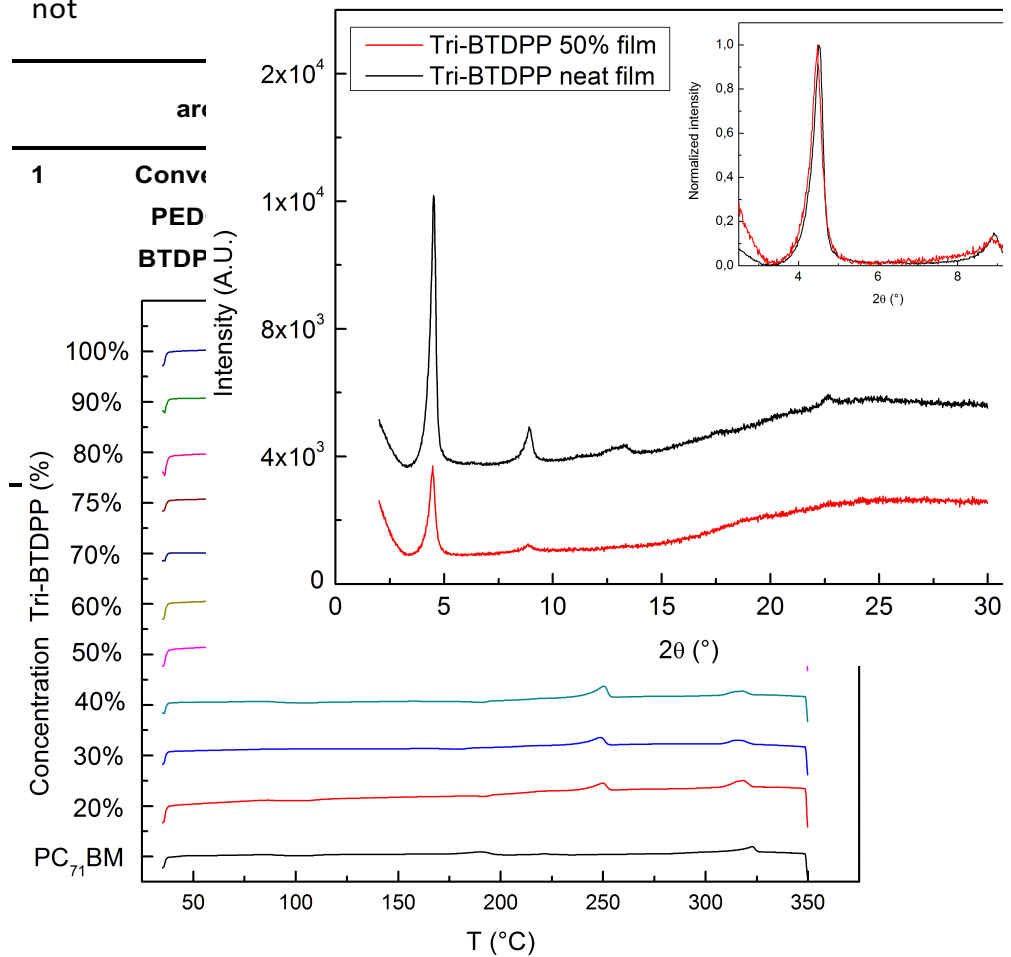

intermix and rather form respective pure crystalline domains, which explains the observed morphology. According to some studies, an ideal morphology should provide not only pure crystalline domains of donor and acceptor to extract the charges but also donor-acceptor intermixed domains. ${ }^{31-33}$ The ultrafast charge separation occurred primarily in intermixed domains. The immiscibility of Tri-BTDPP and $\mathrm{PC}_{71} \mathrm{BM}$ induces

the formation of the over-sized pure crystalline domains and prevents the formation of intermixed domains, leading to hampered exciton diffusion and charge separation.
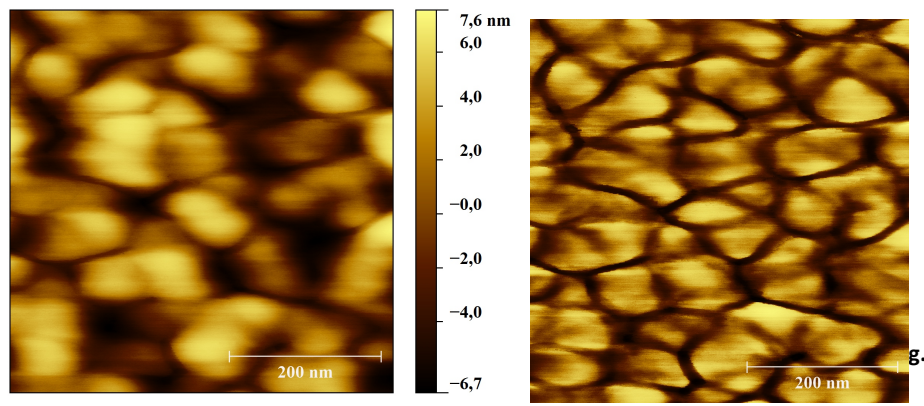

XRD measurements were carried out to study the nature of the molecular packing of the neat Tri-BTDPP and TriBTDPP:PC ${ }_{71}$ BM films. As shown in Fig. 5, for the Tri-BTDPP

neat Fig. 5 XRD measurements on Tri-BTDPP neat film and blend with $\mathrm{PC}_{71} \mathrm{BM}(1: 1)$ 6 DSC first heatifilms 
film, sharp and intense diffraction peaks at $2 \theta=4.50^{\circ}, 8.96^{\circ}$, $13.28^{\circ}, 17.72^{\circ}$ and $22.64^{\circ}$ are clearly seen. According to Bragg's law, the first four peaks represent the $1^{\text {st }}$ to $4^{\text {th }}$ order peaks of planes with a $d$-spacing distance of $1.96 \mathrm{~nm}$, while the last peak represents another set of planes with a $d$-spacing distance of $0.39 \mathrm{~nm}$. This XRD pattern is reminiscent of a lamellar packing motif, which has been frequently observed for many crystalline polymers such as regioregular head-to-tail poly(3hexylthiophene) $(\mathrm{P} 3 \mathrm{HT}) .^{34}$ Therefore it is reasonable to consider that the Tri-BTDPP molecules adopted a lamellar packing motif, with an interlayer distance of $1.96 \mathrm{~nm}$, separated by the alkyl chains, and a $\pi-\pi$ stacking distance of $0.39 \mathrm{~nm}$ between the conjugated backbones. The size of the crystallites was determined from the primary diffraction peak by the Scherrer equation to be $27.4 \mathrm{~nm}$. For the 1:1 TriBTDPP:PC ${ }_{71} B M$ blend film, the primary and secondary diffraction peaks were still observed at the same positions. The size of tri-BTDPP crystallites remained to be $27.4 \mathrm{~nm}$, which confirmed that $\mathrm{PC}_{71} \mathrm{BM}$ did not intermix with Tri-BTDPP to influence the crystal structure of the Tri-BTDPP phase. To achieve a better morphology, the size of Tri-BTDPP's crystallite may have to be reduced to achieve smaller domains. In some accounts, nucleating agents were used to increase the number of nuclei and to limit the formation of large crystals. ${ }^{35,36}$ Alternatively, side chain engineering, e.g., the use of large side chains on the two terminal DPP units, may reduce the crystal size and improve the morphology of the blend films.

\subsection{External quantum efficiency}

To further investigate the photovoltaic process within the device, the external quantum efficiency was measured for optimal solar cells. Fig. 7 shows that the current was mainly generated in the range from $300 \mathrm{~nm}$ to $600 \mathrm{~nm}$. This spectrum region corresponds to the $\mathrm{PC}_{71} \mathrm{BM}$ absorption band, indicating that the current is mainly contributed by the excitons formed within $\mathrm{PC}_{71} \mathrm{BM}$. The lack of tri-BTDPP's exciton contribution can be explained either by the unfavorable morphology that limits charge separation or by the small energy offset between LUMOs of Tri-BTDPP and PC $_{71} B M$ that limits the electron transfer. The morphology had already been shown to be responsible for the limited charge separation due to the oversized Tri-BTDPP grains. The offset between the LUMO of Tri-BTDPP (-3.99 eV) and $\mathrm{PC}_{71} \mathrm{BM}(-4.3 \mathrm{eV})^{37}$ was estimated to be $0.3 \mathrm{eV}$, which is equivalent to the minimal value needed for electron transfer from donor to acceptor. ${ }^{22}$ Therefore, another strategy to improve the cell performance of Tri-BTDPP devices may be to slightly raise the LUMO level of Tri-BTDPP or to use other electron acceptors with lower LUMO levels than that of $P C_{71} B M$.

Fig. 7: EQE and absorption of Tri-BTDPP/PC ${ }_{71} B M$ blend

\section{Conclusions}

A new oligomer semiconductor containing three bisthiopheneDPP units (Tri-BTDPP) was designed and synthesized via Stille

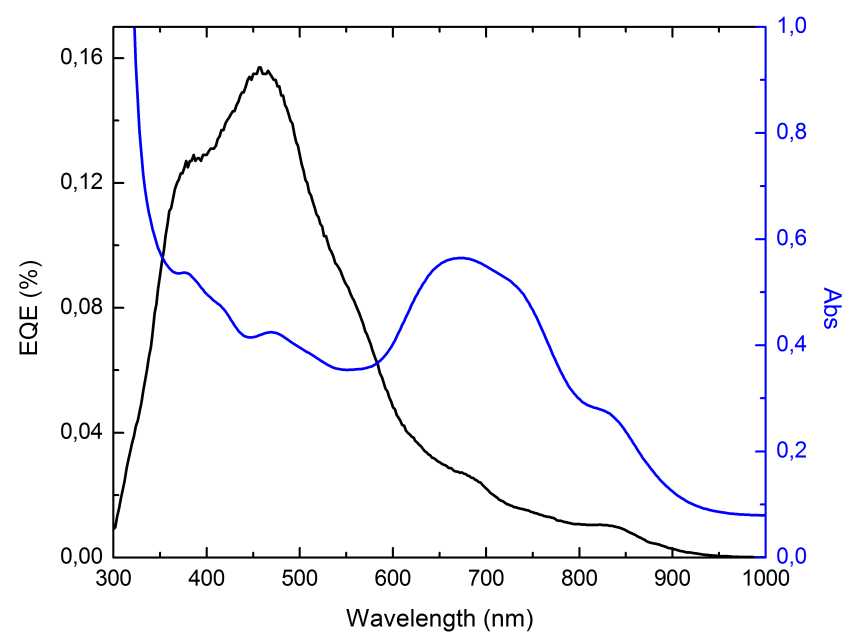

coupling. The extended $\pi$-conjugation and strong intersystem crossing transfer of Tri-BTDPP induced a broad absorption up to the near infrared region ( $1000 \mathrm{~nm}$ ). Tri-BTDPP demonstrated a good hole mobility up to $1.22 \times 10^{-3} \mathrm{~cm}^{2} \mathrm{~V}^{-1} \mathrm{~s}^{-1}$ in solutionprocessed OFET. As an electron donor semiconductor in organic solar cells, Tri-BTDPP exhibited a PCE of $0.72 \%$. A careful study of the morphology by AFM and the interactions between TriBTDPP and $P C_{71} B M$ by DSC and XRD revealed that Tri-BTDPP and $P C_{71} B M$ were unable to intermix effectively, resulting in oversized Tri-BTDPP crystalline phases and thus poor charge separation. Using processing additives or a nucleating agent may be an effective method to improve the morphology of such bulk heterojunction to produce efficient solar cells.

\section{Acknowledgements}

This work was financially supported by the University of Bordeaux and SOLVAY in framework of IDS-FUNMAT network (2012-14-LF). We would like to acknowledge Bertrand Pavageau, Marie-Béatrice Madec and Bin Sun for their contribution in the work.

\section{Notes and references}

1. K. Petritsch, J.J. Dittmer, E.A. Marseglia, R.H. Friend, A. Lux, G.G. Rozenberg, S.C. Moratti and A.B. Holmes, Solar Energy Materials Solar Cells, 2000, 61, 63.

2. M., Riede, T. Mueller, W. Tress, R. Schueppel and K. Leo, Nanotechnology, 2008, 19, 424001.

3. A. Mishra and P. Bäuerle, Angewandte Chemie (International ed. in English), 2012, 51, 2020

4. Y. Li, Q. Guo, Z. Li, J. Pei and W. Tian, Energy \& Environmental Science, 2010, 3, 1427

5. Y. Sun, G. C. Welch, W. L. Leong, C. J. Takacs, G. C. Bazan and A. J. Heeger, Nature materials, 2012, 11, 44

6. J.-L. Wang, Q.-R. Yin, J.-S. Mia, Z. Wu, Z.-F. Chang, Y. Cao, R.B. Zhang, J.-Y. Wang, H.-B. Wu and Y. Cao, Advanced Functional Material, 2015, doi:10.1002/adfm.201500190

7. Y. Liu, C.-C. Chen, Z. Hong, J. Gao, Y. Yang, H. Zhou, L. Dou, G. Li and Y. Yang, Scientific reports, 2013, 3, 3356 
8. Z. He, C. Zhong, S. Su, M. Xu, H. Wu and Y. Cao, Nature Photonics, 2012, 6, 9, 593

9. Y. Huang, X. Guo, F. Liu, L. Huo, Y. Chen, T. P. Russell, C. C. Han, Y. Li, and J. Hou, Advanced Materials, 2012, 24, 3383

10. H.-C. Chen, Y.-H. Chen, C.-C. Liu, Y.-C. Chien, S.-W. Chou, and P.-T. Chou, Chemistry of Materials, 2012, 24, 47664772

11. A. B. Tamayo, B. Walker and T.-Q Nguyen, Journal of Physical Chemistry C, 2008, 112, 11545

12. J. Liu, Y. Sun, P. Moonsin, M. Kuik, C. M. Proctor, J. Lin, B. B Hsu, V. Promarak, A. J. Heeger and T.-Q. Nguyen, Advanced materials (Deerfield Beach, Fla.), 2013, 25, 5898

13. Y. Zhang, M. Xiao, N. Sua, J. Zhonga, H. Tana, Y. Wanga, Y. Liu, Y. Pei, R. Yang and W. Zhu, Organic Electronic, 2015, 17, 198

14. M. Chen, W. Fu, M. Shi, X. Hu, J. Pan, J. Ling, H. Li and H. Chen, Journal of Materials Chemistry A, 2013, 1, 105

15. J. Huang, C. Zhan, X. Zhang, Y. Zhao, Z. Lu, H. Jia, B. Jiang, J. Ye, S. Zhang, A. Tang, Y. Liu, Q. Pei, and J. Yao, ACS Applied Materials \& Interfaces, 2013, 5, 2033

16. S. Loser, C. J. Bruns, H. Miyauchi, R. P. Ortiz, A. Facchetti, S. I. Stupp and T. J. Marks, Journal of the Amercian Chemical Society, 2011, 133, 8142

17. S.-Y. Liu, W.-F. Fu, J.-Q. Xu, C.-C. Fan, H. Jiang, M. Shi, H.-Y. Li, J.-W. Chen, Y. Cao and H.-Z. Chen, Nanotechnology, 2014, 25, 014006

18. J. Lee, M. Jang, S. M. Lee, D. Yoo, T. J. Shin, J. H. Oh, and C. Yang, ACS Applied Materials \& Interfaces, 2014, 6, 20390

19. D. Sahu, C.-H. Tsai, H.-Y. Wei, K.-C. Ho, F.-C. Chang and C.W. Chu, Journal of Materials Chemistry, 2012, 22, 7945

20. W. Hong, S. Chen, B. Sun, M. A. Arnould, Y. Meng and Y. Li, Chemical Science, 2015, 6, 3225

21. B. W. D'Andrade, S. Datta, S. R. Forrest, P. Djurov ich, E. Polikarpov, M. E. Thompson, Organic electronic, 2005, 6, 11.

22. M. C. Scharber, D. Mühlbacher, M. Koppe, P. Denk, C. Waldauf, A. J. Heeger, and C. J. Brabec, Advanced Materials, 2006, 18, 789

23. L. A. Perez, K. W. Chou , J. A. Love, T. S. van der Poll, D.-M. Smilgies, T.-Q. Nguyen, E. J. Kramer, A. Amassian, and G. C. Bazan, Advanced Materials, 2013, 25, 6380

24. Park, J. K., Kim, C., Walker, B., Nguyen, T.-Q. \& Seo, J. H. RSC Advances, 2012, 2, 2232

25. Huang, Q. \& Li, H. Chinese Science Bulletin, 2013, 58, 2677

26. M. A. Ruderer , S. Guo, R. Meier, H.-Y. Chiang, V. Körstgens, J. Wiedersich, J. Perlich, S. V. Roth, and P. Müller-Buschbaum, Advanced Functional Materials, 2011, 21, 3382

27. P.G. Karagiannidis, D. Georgiou, C. Pitsalidis, A. Laskarakis, S. Logothetidis, Materials Chemistry and Physics, 2011, 129 , 1207

28. J. Jo, S.-I. Na, S.-S. Kim, T.-W. Lee, Y. Chung, S.-J. Kang, D. Vak, and D.-Y. Kim, Advanced Functional Material, 2009, 19, 2398

29. P. Peumans, A. Yakimov and S. R. Forrest, Journal of Applied Physics, 2003, 93, 3693

30. W. A. Luhman, R. J. Holmes, Applied Physics Letters, 2009, 94, 153304

31. P. Westacott, J. R. Tumbleston, S. Shoaee, S. Fearn, J. H. Bannock, J. B. Gilchrist, S. Heutz, J. deMello, M. Heeney, H. Ade, J. Durrant, D. S. McPhaila and N. Stingelin, Energy \& Environmental Science, 2013, 6, 2756

32. M. Li, J. Liu, X. Cao, K. Zhou, Q. Zhao, X. Yu, R. Xingab and $Y$. Han, Phys. Chem. Chem. Phys., 2014, 16, 26917

33. M. Scarongella, A. A. Paraecattil, E. Buchaca-Domingo, J. D. Douglas, S. Beaupré, T. McCarthy-Ward, M. Heeney, J.-E. Moser, M. Leclerc, J. M. J. Fréchet, N. Stingelin and N. Banerji, Journal of Materials Chemistry A, 2014, 2, 6218
34. H. Sirringhaus, P. J. Brown, R. H. Friend, M. M. Nielsen, K. Bechgaard, B. M. W. Langeveld-Voss, A. J. H. Spiering, R. A. J. Janssen, E. W. Meijer, P. Herwig, D. M. de Leeuw, Nature, 1999, 401

35. C. Lindqvist, J. Bergqvist, C.-C. Feng, S. Gustafsson, O. Bäcke, N. D. Treat, C. Bounioux, P. Henriksson, R. Kroon, E. Wang, A. Sanz-Velasco, P. M. Kristiansen, N. Stingelin, E. Olsson, O. Inganäs, M. R. Andersson, and C. Müller, Advanced Energy Materials, 2014, 4, 1301437

36. A. Sharenko, N. D. Treat, J. A. Love, M. F. Toney, N. Stingelin and T.-Q. Nguyen, Journal of Materials Chemistry A, 2014, 2, 15717

37. S. Song,Y. Jin, S. H. Park, S. Cho, I. Kim, K. Lee, A. J. Heeger and H. Suh, Journal of Material Chemistry, 2010, 20, 6517 